\title{
VIRULENCE FACTORS OF ESCHERICHIA COLI ISOLATED FROM CALVES WITH DIARRHEA IN BRAZIL
}

\author{
Márcia Regina Salvadori; Geórgio Freesz Valadares ${ }^{1}$; Domingos da Silva Leite ${ }^{1}$; Jesús Blanco²; Tomomasa Yano ${ }^{1 *}$ \\ ${ }^{1}$ Departamento de Microbiologia e Imunologia, Instituto de Biologia, Universidade Estadual de Campinas, Campinas, SP, Brazil. \\ ${ }^{2}$ Departamento de Microbiologia e Parasitologia, Faculdade de Veterinaria, Universidade de Santiago de Compostela, Lugo, Spain.
}

Submitted: August 26, 2002; Returned to Authors: October 18, 2002; Approved: September 25, 2003

\begin{abstract}
Two hundred and five Escherichia coli strains isolated from calves with diarrhea from mid-western Brazil were screened for the presence of virulence factors associated with bovine colibacillosis. One hundred and two $(49.8 \%)$ of the E. coli strains produced toxins: Shiga toxins $1(9.7 \%)$ and $2(6.3 \%), \alpha$-hemolysin $(9.7 \%)$, enterohemolysin (6.8\%), Cytotoxic Necrotizing Factors type 1 (0.5\%), and type 2 (4.4\%), enterotoxins LT-II $(8.3 \%)$ and STa $(3.9 \%)$. No strain produced enterotoxin LT-I. Fimbrial adhesins F5 and F17 were produced by $7.3 \%$ and $4.8 \%$ of the strains, respectivly, and none expressed F41. Seven strains (3.4\%) possessed the gene eae and belonged to serotypes $\mathrm{O} 26: \mathrm{H}-; \mathrm{O} 111: \mathrm{H}-$ and $\mathrm{O} 118: \mathrm{H} 16$. These results suggest that calves in Brazil may be an important source of pathogenic E. coli for animals and humans.
\end{abstract}

Key words: calves, diarrhea, E. coli, virulence factors.

\section{INTRODUCTION}

Escherichia coli is an important pathogen in bovine neonates and may cause intestinal and extraintestinal infections. Bovine E. coli strains can produce Shiga-like toxins (Stx), heatlabile (LT) or heat-stable (ST) enterotoxins, cytotoxic necrotizing factors (CNF1 and CNF2) and hemolysins ( $\alpha$-Hly and E-Hly) (23). The Shiga toxin produced by E. coli strains (STEC) is similar to Shiga-toxin produced by Shigella dysenteriae type 1. E. coli producing Stx-1 and/or Stx-2 is a cause of hemorrhagic colitis (HC) and hemolytic-uremic syndrome (HUS) in humans. Most cases of HC and HUS are caused by ingestion of foods and drinks contaminated with faeces from cattle, specially ground beef, undercooked hamburgers, salami or other foods like raw milk or home made cheese from raw milk. Less frequent modes of transmission of the infection are cattle-to-person or person-to-person direct contact (34), however, asymptomatic STEC infection in household contacts represents a potential source of infection via person-to-person transmission (33).

Epidemiological investigations have shown that cattle frequently excrete strains of STEC in their faeces and this may represent a source of infection (12). Another type of Hly, enterohemolysin (E-Hly), which is different from Hly produced by ETEC strains of porcine origin and by E. coli strains which cause extraintestinal infections in humans, has been described in STEC strains (31).

The principal feature of infections caused by enteropathogenic E. coli (EPEC) is the attaching-and-effacing (A/E) histopathology observed in intestinal biopsies from patients or infected animals (37). The intimate adherence of enteropathogenic $E$. coli to epithelial cells is mediated by a 94$97 \mathrm{KDa}$ outer membrane protein known as intimin, and the gene encoding intimin (eae, for E. coli attaching and effacing) was first reported by Jerse et al (30).

The name enterohemorhagic E. coli (EHEC) has been applied to strains that characterized by their ability to produce Shigalike toxins and to induce attaching and effacing lesions (26).

Enterotoxin-producing E. coli (ETEC) have been identified as the causative agent of several important diarrheal diseases in animals and humans. These bacteria may produce thermolabile (LT-I and LT-II) and thermostable (STa and STb) enterotoxins (21). CNF-producing E. coli, known as necrotizing E. coli

*Corresponding author. Mailing address: Departamento de Microbiologia e Imunologia, Instituto de Biologia, Universidade Estadual de Campinas, Cidade Universitária Zeferino Vaz, Barão Geraldo. 13081-970, Campinas, SP, Brasil. Tel.: (+5519) 3788-6254. Fax: (+5519) 3788-7050. E-mail: tyano@obelix.unicamp.br 
(NTEC), have been isolated from animals with enteritis (19) and from humans with extraintestinal infections (14). NTEC can produce two types of CNF (CNF1 or CNF2) that can be distinguished by the morphological alterations induced in $\mathrm{HeLa}$ cells, by cross-neutralization assays, by the specific necrotizing activity of CNF2 in mouse footpads, and by the presence of other virulence factors associated with NTEC (20). CNF1 is produced by $\alpha$-hemolysin-positive $E$. coli strains that cause extraintestinal infections in humans (8).

E. coli strains can also produce a variety of adhesins that promote the attachment of bacteria to cell surface receptors and to components of the extracellular matrix. Although the strains which cause infections in humans are well characterized, there is limited information on those which cause diseases in animals (3). The fimbrial adhesin F5 (K99) plays a role in the colonization of enterotoxigenic E. coli in epithelial cells of the small intestine of calves (1) and occasionally piglets (35). Other fimbriae (F41 and F17) have also been identified in enterotoxigenic $E$. coli isolated from calves $(36,39)$.

In this study, we investigated the prevalence of virulence factors associated with the pathogenicity of $E$. coli isolated from calves with diarrhea, using phenotypic and genotypic (Polymerase Chain Reaction - PCR) assays.

\section{MATERIALS AND METHODS}

\section{Bacterial strains}

Two hundred and five $E$. coli strains isolated from 139 fecal samples of 139 diarrheic neonatal calves, with ages up to 60 days, provided by the Centro Nacional de Pesquisa de Gado de Corte, EMBRAPA, Campo Grande, MS. Brazil, were screened for the presence of virulence factors. Standard bacteriological methods were used to isolate and identify the E. coli strains. The reference $E$. coli strains used as positive and negative controls were $\mathrm{H} 30\left(\mathrm{O} 26: \mathrm{H} 11 \mathrm{Stx}^{+}\right)$, J2 (O157:H- Stx-2 $\left.2^{+} e a e^{+}\right)$, $\mathrm{H} 10407\left(\mathrm{LT}^{-\mathrm{I}^{+}}\right.$and STa $\left.{ }^{+}\right), \mathrm{PCD}\left(\mathrm{LT}^{-} \mathrm{II}^{+}\right), 40 \mathrm{MR} 48\left(\mathrm{CNF}^{+}\right)$, B26a $\left(\mathrm{CNF}^{+}\right), \mathrm{C} 3888\left(\mathrm{E}-\mathrm{Hly}^{+}\right), \mathrm{B} 41 \mathrm{M}\left(\mathrm{O} 101: \mathrm{K}-\mathrm{F} 41^{+}\right), \mathrm{F} 82$ (O101:

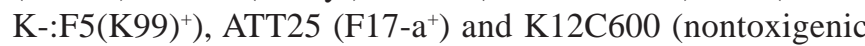
strain). All strains were stored in trypticase soy agar (TSA) (BBL, Cockeysville, USA) at room temperature.

\section{Toxin production}

For the production of Stx, heat-labile enterotoxin LT and heat-stable STa, bacteria were cultured in BHI (Difco, Detroit, USA) and incubated at $37^{\circ} \mathrm{C}$ with shaking (150 rpm). After 18 hours, the cultures were centrifuged at $10.000 \mathrm{x} g$ at $4^{\circ} \mathrm{C}$ for 15 $\mathrm{min}$. The supernatants were filtered through $0.22 \mu \mathrm{m}$ membrane filters (Millipore Corp., Bedford, USA) and stored at $-20^{\circ} \mathrm{C}$. CNF production by $E$. coli strains was assessed in the presence of mytomycin C $(1 \mu \mathrm{g} / \mathrm{mL})$ as described by Blanco et al. (7). The culture supernatants of all strains were tested in duplicate for detection of STx, CNF and LT toxins on Vero (African Green
Monkey Kidney) cells supplied by Fort Dodge Laboratories, Inc. (Campinas, Brazil). Cytotoxic activity was detected as reported by Yano et al. (46). STa was detected by intragastric inoculation of $E$. coli culture supernatant in the suckling mouse assay as described by Dean et al. (16).

\section{Hemolysin production}

For the detection of $\alpha$-Hly E. coli strains were plated on sheep blood-agar and incubated at $37^{\circ} \mathrm{C}$ for $18 \mathrm{~h}$. E-Hly was detected on Beutin basic medium (5) containing $\mathrm{CaCl}_{2}$ (Merck) and washed sheep erythrocytes after incubation at $37^{\circ} \mathrm{C}$ for $18 \mathrm{~h}$.

\section{Phenotypic detection of fimbriae}

E. coli strains were cultured overnight at $37^{\circ} \mathrm{C}$ on Minca medium (26). The detection of F5, F17 and F41 fimbriae was done by the slide agglutination test using specific antiserum produced in our laboratory using reference strains. Each antiserum was absorbed with its homologous strain grown at $16^{\circ} \mathrm{C}$ before use.

\section{Detection of virulence factors by PCR}

Total bacterial DNA were prepared as described by Blanco et al. (13). The base sequences, annealing temperatures and predicted sizes of the amplified products for the specific oligonucleotide primers used in this study are shown in Table 1. The analysis of the PCR products was performed in $2 \%$ horizontal agarose gel eletrophoresis stained with ethidium bromide under UV light.

\section{Serogrouping and Serotyping}

Serogrouping of the STEC strains associated with the eae gene was done using a microplate technique described by Guinée et al. (24) and modified by Blanco et al. (8), we used a kit containing all the 173 antisera, purchased from the Laboratório de Referência en Escherichia coli (LREC) from the Universidade de Santiago de Compostela in Lugo, Spain. The serotyping assays were kindly performed by Jesús Blanco, in the LREC.

\section{RESULTS}

\section{Production of toxins}

Two hundred and five strains of E. coli isolated from 139 calves with diarrhea were assayed for the production of Stx, CNF, LT and STa toxins. The toxins detected were: Stx-1 20 (9.75\%), Stx-2 13 (6.34\%), CNF1 1 (0.5\%), CNF2 9 (4.4\%), LT-II $17(8.3 \%)$, and STa 8 (3.9\%). No strains produced LT-I. Some strains produced more than one toxin (Table 2).

\section{Hemolysin production}

Of the 205 E. coli strains, $20(9.8 \%)$ were $\alpha-\mathrm{Hly}^{+}$and 14 $(6.8 \%)$ were E-Hly ${ }^{+}$(Table 2). Two (1\%) of $\alpha-\mathrm{Hly}^{+}$strains were also CNF-producing strains. There was, a high association 
Table 1. PCR primers used in this study.

\begin{tabular}{|c|c|c|c|c|}
\hline Primer & Sequence $(5-3)$ & $\begin{array}{l}\text { Size of amplified product } \\
\text { (base pairs) }\end{array}$ & $\begin{array}{c}\text { Annealing } \\
\text { temperature }\left({ }^{\circ} \mathrm{C}\right)\end{array}$ & Reference \\
\hline eae & $\begin{array}{c}5 \text {-GACCCGGCAACAAGCATAAGC -3 } \\
5 \text {-CCACCTGCAGCAACAAGAGG-3 }\end{array}$ & 384 & 55 & (39) \\
\hline CNF1 & $\begin{array}{c}5 \text {-GAACTTATTAAGGATAGT -3 } \\
5 \text {-CATTATTTATAACGCTG -3 }\end{array}$ & 543 & 45 & (10) \\
\hline $\mathrm{CNF} 2$ & $\begin{array}{l}5 \text {-AATCTAATTAAAGAGAAC -3 } \\
5 \text {-CATTATTTATAACGCTG }-3\end{array}$ & 543 & 44 & (10) \\
\hline LT-I & $\begin{array}{l}5 \text {-TATCCTCTCTATATGCACAG }-3 \\
5 \text { - CTGTAGTGGAAGCTGTTATA }-3\end{array}$ & 480 & 48 & (14) \\
\hline LT-II & $\begin{array}{l}5 \text {-AGATATAATGATGGATATGTATC }-3 \\
5 \text {-TAACCCTCGAAATAAATCTC }-3\end{array}$ & 300 & 48 & (41) \\
\hline STa & $\begin{array}{l}5 \text {-TCCGTGAAACAACATGACGG -3 } \\
5 \text {-ATAACATCCAGCACAGGCAG -3 }\end{array}$ & 244 & 60 & (43) \\
\hline Stx-1 & $\begin{array}{l}5 \text {-AGG TTGCAGCTCTCTTTCAATA -3 } \\
5 \text {-TGCAAACAAATTATCCCCTGAG -3 }\end{array}$ & 364 & 57 & $(28)$ \\
\hline Stx-2 & $\begin{array}{c}5 \text {-GGGCAGTTATTTTGCTGTGGA -3 } \\
5 \text {-GTATCTGCCTGAAGCGTAA -3 }\end{array}$ & 386 & 59 & (27) \\
\hline F5(K99) & $\begin{array}{l}5 \text {-TGGGACTACCAATGCTTCTG -3 } \\
5 \text {-TATCCACCATTAGACGGAGC -3 }\end{array}$ & 450 & 60 & $(40)$ \\
\hline F17 & $\begin{array}{ll}5 & \text {-GCAGAAAATTCAATTTATCCTTGG } \\
5 & -3 \\
\text {-CTGATAAGCGATGGTGTAATTAAC } & -3\end{array}$ & 537 & 65 & (3) \\
\hline F41 & $\begin{array}{l}5 \text {-GAGGGACTTTCATCTTTTAG -3 } \\
5 \text {-AGTCCATTCCATTTATCGGC -3 }\end{array}$ & 431 & 56 & $(21)$ \\
\hline
\end{tabular}

Table 2. Toxigenic and hemolytic E. coli strains isolated from calves with diarrhea.

\begin{tabular}{cc}
\hline Toxins & No. (\%) of $\boldsymbol{E}$. coli strains \\
\hline CNF1 & $1(0.5)$ \\
CNF2 & $2(1.0)$ \\
LT-I & 0 \\
Stx-1 & $6(2.9)$ \\
Stx-2 & $4(1.9)$ \\
LT-II & $14(6.8)$ \\
Sta & $4(1.9)$ \\
$\alpha-H l y$ & $18(8.7)$ \\
E-Hly & $3(1.5)$ \\
CNF2 and Stx-1 & $1(0.5)$ \\
Stx-1 and Stx-2 & $2(1.0)$ \\
CNF2 and LT-II & $1(0.5)$ \\
CNF2 and STa & $2(1.0)$ \\
Stx-1 and LT-II & $1(0.5)$ \\
CNF2 and LT-II and STa & $1(0.5)$ \\
$\alpha-H l y$ and CNF2 & $2(1.0)$ \\
E-Hly and Stx-1 & $3(1.5)$ \\
E-Hly and Stx-2 & $6(2.9)$ \\
E-Hly and STa and Stx -2 & $1(0.5)$ \\
\hline
\end{tabular}

between E-Hly ${ }^{+}$and $\mathrm{Stx}^{+}$, with 11 strains (5.3\%) expressing both (Table 2). None of the strains producing Hly were associated with enterotoxins.

\section{Production of fimbriae}

Of the strains isolated, 15 (7.3\%) were $\mathrm{F}^{+}, 10$ (4.9\%) were $\mathrm{F} 17^{+}$and none produced $\mathrm{F} 41$. The $\mathrm{F} 5$ and $\mathrm{F} 17$ positive strains were related to $7(3.4 \%)$ and $5(2.4 \%)$ toxigenic strains respectively, (Table 3).

Table 3- Fimbrial adhesins and eae* producing E. coli strains isolated from calves with diarrhea and the associated toxins.

\begin{tabular}{cc}
\hline Fimbriae & No. (\%) of strains \\
\hline F5 & $6(2.9)$ \\
F17 & $5(2.4)$ \\
F41 & 0 \\
F5 and Stx-2 & $2(1.0)$ \\
F5 and Sta & $4(1.9)$ \\
F5 and $\alpha-H l y$ & $1(0.5)$ \\
F5 and E-Hly & $2(1.0)$ \\
F17 and LT-II & $5(2.4)$ \\
Stx-1 and eae & $6(2.9)$ \\
E-Hly and Stx-1 and eae & $1(0.5)$ \\
\hline
\end{tabular}

* - eae detection by PCR assays only. 


\section{Genotypic assays}

The results obtained in phenotypic assays were later confirmed by Polymerase Chain Reaction (PCR). Only the eae detection assays were made by PCR alone.

\section{Analysis of strains producing Stx}

Of 33 STEC, 7 (21.2\%) showed the eae gene (Table 2), and belonged to serogroups O11 (1), O26 (1), O111 (1), O118 (2) and O153 (1); one strain was not typed. The strains of the serogroups O26, O11 and $\mathrm{O} 118$ were later assayed for determination of $\mathrm{H}$ (flagellar) antigen, and their serotypes were : O26:NM; O111:NM; O118:H14 and O118:H16.

\section{DISCUSSION}

Since colibacillosis is an important cause of economic loss on farms, detailed studies of the virulence factors produced by E. coli strains in farm animals are needed. Colibacillosis is common in Brazil, but the few studies reported so far have dealt with a restricted number of animals and regions, and represent only a small sample of the total brazilian bovine herd. For this study, we chose the State of Mato Grosso do Sul in mid-western Brazil which has the largest bovine herd in the country (27). From the 205 E.coli strains, we found 83 (40.05\%) strains positive for at least one of the virulence factors involved in this study.

We found $20(9.75 \%)$ e $13(6.34 \%)$ positive strains for Stx-1 and Stx-2 respectively (Table 2); investigations by Blanco et al. (10) found a rate of Stx-1 and Stx-2 producing strains in Spain similar to our data. Among those $\mathrm{Stx}^{+}$strains, 7 were positive for eae gene, belonging to the serogroups (O11, O26, O111, $\mathrm{O} 118, \mathrm{O} 153)$; then determined the type of flagellar antigen of these strains and their serotypes are: O26:H-; O111:H-; O118:H14 and O118:H16; according to Mainil (34) and Nataro and Kaper (37), strains from these serotypes are EHEC strains. The most important animal species in terms of human infection by EHEC is cattle and high rates of colonization by Stx-positive E. coli have been found in bovine herds in many countries (37). Our findings suggests that cattle is an important reservoir of STEC and EHEC in Brazil. There is a previous report (2) of $e a e^{+}$strains isolated from bovines in Brazil, but these strains were not positive for any enterotoxin or cytotoxin.

Blanco et al. (9) reported that $62 \%$ of Stx-producing strains from cattle and humans produced E-Hly. However, we observed only $35.5 \%$ of E-Hly ${ }^{+}$strains associated with Stx synthesis. It is unclear whether the absence of hemolytic activity in some STEC strains corresponds to a characteristic phenotype, since the Stx and E-Hly phenotypes are not always stably inherited in certain E. coli strains (31).

One $(0.5 \%)$ and nine $(4.4 \%)$ of the culture supernatants of the 205 E. coli strains produced CNF1 and CNF2, respectively. These results are comparable to those recently reported by
Orden et al. (38). We observed a low association between the production of CNF and a-Hly, in contrast to other reports (9). CNF2 and Stx production were associated in one of the strains (Table 2). The significance of this observation in relation to pathogenesis is unclear. However, even with the potential mobility of cnf2, the production of both CNF2 and Stx-1 (0.5\%) by the same strain remains a rare event (39).

For the enterotoxins, we found eight (3.9\%) STa positive strains. Such a low frequency may be comparable to French $(0 \%)$ and Spanish $(1.3 \%)$ data $(18,6)$. No LT-I positive strain was found. Interestingly, we found $17(8.3 \%)$ strains positive for LTII, in contrast with the fact that there are few reports of the incidence of this toxin in human and animals (26). In 2002, Ugrinovich et al. reported, for the first time, the isolation of a $\mathrm{LT}^{-\mathrm{II}^{+}}$strain among 52 isolates in Brazil (45).

Fimbrial adhesin F5 plays a role in the colonization of bovine small intestine epithelial cells by ETEC (1). F5 and heat-stable toxin (ST)-producing $\left(\mathrm{F}^{+}\right.$and $\left.\mathrm{STa}^{+}\right)$strains occur frequently in calves in several countries (9). Our results (Table 3 ) were similar to those of Blanco et al. (6) in Spain, who detected $\mathrm{F}^{+} \mathrm{STa}^{+}$ strains in $1 \%$ of their cases. We also isolated $10(4.8 \%) \mathrm{F}^{2} 7^{+}$ strains, which is comparable to the frequency reported by Shimizu et al. (43) and Leite et al. (32). F5 and F17 were associated with other toxins (Table 3). None of the strains produced F41 fimbriae (17).

In conclusion, these results show that bovine $E$. coli produce several toxins and colonization factors (Tables 2 and 3), some of which may be involved in human diseases. More extensive studies involving a larger number of animals of different bovine races and types of farms (dairy or meat) are required in order to establish precisely the identity and prevalence of virulence factors associated with colibacillosis in Brazil. Such studies will provide important epidemiological data about this disease.

\section{ACKNOWLEDGEMENTS}

This work was supported by the Fundação de Amparo à Pesquisa do Estado de São (FAPESP, grant 97/7729-1). M. R. Salvadori and G. F. Valadares are supported by fellowships from FAPESP (grants 00/06841-7 and 00/01399-4, respectively). The authors thank Ana Stella Menegon Degrossoli for technical assistance.

\section{RESUMO}

\section{Fatores de virulência das amostras de Escherichia coli isoladas de bezerros com diarréia no Brasil}

Duzentas e cinco amostras de Escherichia coli isoladas de bezerros com diarréia da região centro oeste do Brazil foram examinados quanto a presença de fatores de virulência associados à colibacilose bovina. Cento e duas amostras $(49,8 \%)$ 
de E. coli produziram toxinas: toxina de Shiga do tipo $1(9,7 \%)$ e $2(6,3 \%), \alpha$-hemolisina $(9,7 \%)$, enterohemolisina $(6,8 \%)$, Fatores Citotóxicos Necrotisantes tipo $1(0,5 \%)$ e $2(4,4 \%)$, enterotoxinas LT-II $(8,3 \%)$, e STa $(3,9 \%)$. Nenhuma amostra produziu enterotoxina LT-I. Adesinas fimbriais F5 e F17 foram produzidas por $7,3 \%$ e $4,8 \%$ das cepas, respectivamente, e nenhuma expressou F41. Sete das amostras $(3,4 \%)$ apresentaram o gene eae e pertenceram aos sorotipos $\mathrm{O} 26: \mathrm{H}-; \mathrm{O} 111: \mathrm{H}-$ e O118:H16. Estes resultados sugerem que bezerros no Brasil podem ser uma importante fonte de E. coli patogênica para animais e humanos.

Palavras-chave: bezerros, diarréia, E. coli, fatores de virulência.

\section{REFERENCES}

1. Acres, S.D. A review: enterotoxigenic Escherichia coli infections in newborn calves. J. Dairy Sci., 68:229-256, 1985.

2. Aidar, L.; Penteado, A.S.; Trabulsi, L.R.; Blanco, J.E.; Blanco, M.; Blanco, J.; Pestana de Castro, A.F. Subtypes of intimin among nontoxigenic Escherichia coli from diarrheic calves in Brazil. Can. J. Vet. Res., 64(1):15-20. 2000.

3. Babai, R.; Blum-Oehler, G.; Stern, B.E.; Hacker, J.; Zon, E.Z. Virulence patterns from septicemic Escherichia coli O78 strains. FEMS Microbiol. Letts., 149:99-105, 1997.

4. Bertin, Y.; Martin, C.; Oswald, E.; Girardeau, J.P. Rapid and specific detection of F17-related pilin and adhesin genes in diarrheic and septicemic Escherichia coli strains by multiplex PCR. J. Clin. Microbiol., 34:2921-2928, 1996.

5. Beutin, L. The different hemolysins of Escherichia coli. Med. Microbiol. Immunol., 180:167-182, 1991.

6. Blanco, J.; Gonzalez, E.A.; Garcia, S.; Blanco, M.; Regueiro, B.; Bernardez, I. Production of toxins by Escherichia coli strains isolated from calves with diarrhea in Galicia (North-western Spain). Vet. Microbiol., 18:297-311, 1988.

7. Blanco, J.; Blanco, M.; Gonzalez, E.A.; Alonso, M.P.; Garabal, J.I. Comparative evaluation of three tests for the detection of Escherichia coli cytotoxic necrotizing factors (CNF1 and CNF2) using filtrates of cultures treated with mitomycin C. FEMS Microbiol. Lett., 69:311316, 1990.

8. Blanco, J.; Blanco, M.; Alonso, M.P.; Blanco, J.E.; Garabal, J.I.; González, E.A. Serogroups of Escherichia coli strains producing cytotoxic necrotizing factors CNF1 and CNF2. FEMS Microbiol. Lett., 96:155-160, 1992a.

9. Blanco, M.; Blanco, J.; Gonzalez, E.A.; Garabal, J.I.; Blanco, J.E. Escherichia coli toxigénicos de origen bovino. Med. Vet., 9:199213, 1992b.

10. Blanco, M.; Blanco, J.; Blanco, J.E.; González, E.A.; Gomes, A.T.; Zerbini, L.F.; Yano, T.; Pestana de Castro, A.F. Genes coding for Shiga-like toxins in bovine verotoxin-producing Escherichia coli (VTEC) strains belonging to different O:K:H serotypes. Vet. Microbiol., 42:105-110, 1994.

11. Blanco, M.; Blanco, J.E.; Blanco, J.; Alonso, M.P.; Balsanobre, C.; Mouriño, M.; Madrid, C.; Juárez, A. Polymerase chain reaction for detection of Escherichia coli strains producing cytotoxic necrosing factor type 1 and type 2 (CNF1 and CNF2). J. Microb. Meth., 26:95-101, 1996a.

12. Blanco, M.; Blanco, J.E.; Blanco, J.; Gonzalez, E.A.; Alonso, M.P.; Maas, H.; Jansen, W. H. Prevalence and characteristics of human and bovine verotoxigenic Escherichia coli strains isolated in Galicia (north-western Spain). Eur. J. Epidemiol., 12:13-19, 1996b.
13. Blanco, M.; Blanco, J.E.; Mora, A.; Blanco, J. Distribution and characterization of faecal necrotoxigenic Escherichia coli $\mathrm{CNF}^{+}$ and $\mathrm{CNF}_{2}{ }^{+}$isolated from healthy cows and calves. Vet. Microbiol., 59:183-192, 1998.

14. Caprioli, A.; Falbo, V.; Ruggeri, F.M.; Baldassarri, L.; Bicicchia, R.; Ippolito, G.; Romoli, E.; Donelli, G. Cytotoxic necrotizing factor prodution by hemolytic strains of Escherichia coli causing extraintestinal infections. J. Clin. Microbiol., 25:146-149, 1987.

15. Dallas, W.S.; Falkow, S. Amino acid sequence homology between cholera toxin and Escherichia coli heat-labile toxin. Nature, 288: 499-501, 1980.

16. Dean, A.G.; Ching, Y.C.; Williams, R.G.; Harder, L.B. Test for Escherichia coli enterotoxin using infant mice: Application in a study of diarrhoea in children in Honolulu. J. Infect. Dis., 125:407411, 1972.

17. De Graaf, F.K.; Rooda, I. Production, purification and characterization of the fimbrial adhesive antigen F41 isolated from the calf enteropathogenic Escherichia coli strains B41M. Infect. Immun., 36:751-758, 1982.

18. De Rycke, J.; Bernard, S.; Laport, J.; Naciri, M.; Popoff, M.R.; Rodolakis, A. Prevalence of various enteropathogens in the faeces of diarrheic and healthy calves. Ann. Rech. Vet., 17:159-168, 1986.

19. De Rycke, J.; Guillot, J.F.; Boivin, R. Cytotoxins in nonenterotoxigenic strains of Escherichia coli isolated from faeces of diarrheic calves. Vet. Microbiol., 15:137-150, 1987.

20. De Rycke, J.; Gonzalez, E.A.; Blanco, J.; Oswald, E.; Blanco, M.; Boivin, R. Evidence for two types of cytotoxic necrotizing factor in human and animal clinical isolates of Escherichia coli. J. Clin. Microbiol., 28:694-699, 1990.

21. Elwell, L.P. Plasmid-mediated factors associated with virulence of bacteria to animals. Ann. Rev. Microbiol., 34:465-496, 1980.

22. Fidock, D.A.; McNicholas, P.A.; Lehrbach, P.R. Nucleotide sequence of the F41 fimbriae subunit gene in Escherichia coli B41. Nucleic Acids Res., 17:2849, 1989.

23. Gay, C.C.; Besser, T.E. Escherichia coli septicaemia in calves. In: Gyles, C.L. (ed.), Escherichia coli in Domestic Animals and Humans, 1th ed. CAB International, Wallingford, UK, 1994, p.75.

24. Guinée, P.A.M.; .Agterberg, C.M.; Jansen, W.H. Escherichia coli O antigen typing by means of a mechanized microtechnique. Appl. Microbiol., 24:127-131, 1972.

25. Guinée, P.A.M.; Veltkamp, J.; Jansen, W.H. Improved Minca medium for the detection of K99 antigen in calf enterotoxigenic strains of Escherichia coli. Infect. Immun., 15:676-678, 1977.

26. Gyles, C.L. Escherichia coli Enterotoxins, In Escherichia coli in Domestic Animals and Humans, 1th ed. CAB International, Wallingford, UK, 1994, p. 346.

27. Instituto Brasileiro de Geografia e Estatística (IBGE). Anuário Estatístico Brasileiro, Ed. DEDIT/CDDI, Rio de Janeiro Brazil. 56:3-84, 1996.

28. Jackson, M.P.; Neill, R.J.; O’Brien, A.D.; Holmes, R.K.; Newland, J.W. Nucleotide sequence analysis and comparison of the structural genes for Shiga-like toxin I and Shiga-like toxin II encoded by bacteriophages from Escherichia coli. FEMS Microbiol. Lett., 44:109-114, 1987.

29. Jackson, M.P.; Newland, J.W.; Holmes, R.K.; O’Brien, A.D. Nucleotide sequence analysis of the structural genes for shiag. Microbiol. Pathogen., 2:147-153, 1988.

30. Jerse, A.E.; Yu, J.; Tall, B.D.; Kapper, J.B. A genetic locus of enteropathogenic Escherichia coli necessary for the production of attaching and effacing lesions on tissue culture cells. Proc. Natl. Acad. Sci. USA., 87:7839-7843, 1990.

31. Karch, H.; Meyer, T.; Russmann, H.; Heesemann, J. Frequent loss of Shiga-like toxin genes in clinical isolates of Escherichia coli upon subcultivation. Infect. Immun., 8(60):3464-3467, 1992.

32. Leite, D.S.; Garcia, M. ; Yano, T.; Castro, A.F.P. Detecção da adesina FY em amostras de Escherichia coli isoladas de bezerros com diarréia no Brasil. Rev. Microbiol., 20:292-295, 1989. 
33. Ludwig, K.; Sarkim, V.; Bitzan, M.; Karmali, M.A.; Bobrowski, C.; Ruder, H.; Laufs, R.; Sobottka, I.; Petric, M.; Karch, H.; MüllerWiefel, D.E. Shiga Toxin-Producing Escherichia coli Infection and Antibodies against Stx2 and Stx1 in Household Contacts of Children with Enteropathic Hemolytic-Uremic Syndrome. J. Clin. Microbiol., 40:1773-1782, 2002.

34. Mainil, J. Shiga/Verocytotoxins and Shiga/verotoxigenic Escherichia coli in animals. Vet. Res., 30:235-257, 1999.

35. Moon, H.W.; Nagy, B.; Isaacson, R.E.; Ørskov, I. Occurrence of K99 antigen on Escherichia coli isolated from pigs and colonization of pig ileum by $\mathrm{K}^{+} 9^{+}$enterotoxigenic $E$. coli from calves and pigs. Infect. Immun., 15:614-620, 1977.

36. Morris, J.A.; Thorns, C.; Scott, A.C.; Sojka, W.J.; Wells, G.A. Adhesions in vitro and in vivo associated with an adhesive antigen (F41) produced by a K99 mutant of the reference strain Escherichia coli B41. Infect. Immun., 36:1146-1153, 1982.

37. Nataro, P.J.; Kaper, J.B. Diarrheagenic Escherichia coli. Clin Microbiol. Rev., 11:142-201, 1998.

38. Orden, J.A.; Ruiz-Santa-Quiteria, J.A.; Cid, D.; García, S.; de la Fuente, R. Prevalence and characteristics of necrotoxigenic Escherichia coli (NTEC) strains isolated from diarrhoeic dairy calves. Vet. Microbiol., 66:265-273, 1999

39. Oswald, E.; Pohl, P.; Jacquemin, E.; Lintermans, P.; Van Muylen, K.; O'Brien, A.D.; Mainil, J. Specific DNA probes to detect Escherichia coli strains producing cytotoxic necrotising factor type 1 or type 2 . J. Med. Microbiol., 40:428-434, 1994.
40. Paton, A.W.; Paton, J.C. Detection and characterization of shiga toxigenic Escherichia coli by using multiplex PCR assays for $s t x_{1}$, st $x_{2}$, eaeA, enterohemorrhagic E. coli hlyA, rfb $b_{0111}, r f b_{0157} . J$. Clin Microbiol., 36:598-602, 1998.

41. Roosendaal, B.; Gaastra, W.; De Graaf, F.K. The nucleotide sequence of the gene encoding the K99 subunit of enterotoxigenic Escherichia coli. FEMS Microbiol. Lett., 22:253-258, 1984.

42. Schultsz, C.; Pool, G.J.; van Ketel, R.; de Wever, B.; Speelman, P.P.; Dankert, J. Detection of enterotoxigenic Escherichia coli in stool samples by using nonradioactively labeled oligonucleotide DNA probes and PCR. J. Clin. Microbiol., 32:2393-2397, 1994.

43. Shimizu, M.; Sakano, T.; Yamamoto, J.; Kitajima, K. Incidence and some characteristics of fimbriae FY and 31A of Escherichia coli isolates from calves with diarrhea in Japan. Microbiol. Immunol., 31:417-426, 1987.

44. So, M.; McCarthy, B.J. Nucleotide sequence of the bacterial transposon Tn1681 encoding a heat-stable (ST) toxin and its identification in enterotoxigenic Escherichia coli strains. Proc. Natl. Acad. Sci. USA., 77:4011-4015, 1980.

45. Ugrinovich, L.A.; Ávila, F.A.; Oliveira, M.A.; Pestana de Castro, A.F Identificação dos genes que codificam para a enterotoxina termolábil LT-II em amostras de Escherichia coli isoladas de bezerros com diarréia na região de Jaboticabal, SP, Brasil. Ciência Rural, 32:289-291. 2002.

46. Yano, T.; Tamashiro, W.M.S.C.; Garcia, M.; Pestana de Castro, A.F. Detecção de verocitotoxina (VT) em amostras de Escherichia coli isoladas de bezerro com diarréia. Rev. Microbiol., 17:339-341, 1986. 